\title{
The Radiological Exposure from the Perspective of the Interventional Cardiologist
}

\author{
Pedro Beraldo de Andrade ${ }^{1,2}$ e André Labrunie ${ }^{1,2}$ \\ Santa Casa de Marília, ${ }^{1}$ Marília, SP - Brazil \\ Hospital do Coração de Londrina, ${ }^{2}$ Londrina, $P R$ - Brazil \\ Short Editorial related to the article: Prevalence of Lens Opacity in Interventional Cardiologists and Professional Working in the \\ Hemodynamics in Brazil
}

The interventional cardiology represents an area in constant development and it has advanced considerably in the treatment of both congenital and acquired cardiovascular diseases. It has a safe and effective role in the correction of septal and shunt ${ }^{1}$ congenital abnormalities, valve diseases, especially the percutaneous treatment of the aortic stenosis in patients with high or intermediate ${ }^{2,3}$ surgical risk and, more recently, it has also moved towards the mitral and tricuspid apparatuses. ${ }^{4,5}$

The percutaneous coronary intervention has stood out in the treatment of lesions of the left main coronary artery and multivessel coronary artery disease, in the absence of high anatomical complexity, ${ }^{6}$ reaching now the frontier of chronic occlusions with consistent results. ${ }^{7}$

The technical challenges impose greater risks to the occupational health of those involved in the daily routine of a cardiac catheterization laboratory, especially the interventional cardiologists. Beyond musculoskeletal or orthopedic abnormalities, related to wearable plumbing aprons, current evidence suggests that the extended radiological exposure would cause a fourfold and a half greater risk of cancer and a nine fold greater risk of cataract among these professionals. ${ }^{8}$ Besides, chronic low doses of ionizing radiation could promote

\section{Keywords}

Cardiology, Interventional/trends; Heart, Defects, Congenital; Percutaneous Coronay Intervention; Cardiovascular Diseases/ prevention and control; Radiation Exposure/adverse effects.

Mailing Address: André Labrunie •

Rua Paes Leme, 1351. Postal Code 86010-610, Jd. Ipiranga, Londrina, PR - Brazil E-mail: alabrunie@cardiol.br, alabrunie@hospcoracao.com.br

DOI: $10.5935 /$ abc. 20190052 changes in the endothelial cellular biology, resulting in vascular damage, subclinical atherosclerosis and a greater prevalence of cardiovascular disease. ${ }^{9}$

In the present issue of the Arquivos Brasileiros de Cardiologia, Barbosa AHP et al., ${ }^{10}$ describe, in a pioneering way, the deleterious effects of the radiological exposure in a voluntary sample of interventional cardiologists, with nationwide representativity. In the exposed group, the prevalence of subcapsular posterior cataract, the most frequent variant found in this scenario, was $13 \%$, compared to $2 \%$ in the control group $(p=0.0081)$, in consonance with the findings from the international literature. In an alarming way, the authors report a lower than the desired and recommended frequency of the use of adjustable positioning shields, such as suspended screen and lead strips positioned the side of the examination table, as well as protective goggles. The implementation of such preventive actions has proved to reduce radiological exposure to the operators. ${ }^{11}$

The risks inherent in the chronic exposure to the ionizing radiation certainly characterize a topic of extreme relevance and it is necessary to take them into account in the professional quality standards that guide the speciality, as well as in the employment relations. Individually, how many professionals would abdicate this area of medicine because of this hazard? As an inference to this questioning, we have witnessed a recent paradigm shift in relation to the vascular access in the performance of coronary artery invasive procedures, with the preferential choice for the radial technique in lieu of the femoral one. This strategy has benefitted the patients, with the reduction of the complications regarding the site of the arterial puncture, the rate of major bleeding as well as morbidity and mortality, but at the cost of a greater and proved radiological exposure to the operator. ${ }^{12}$

May the interventional cardiologists have the last word. 


\section{Short Editorial}

\section{References}

1. Turner DR, Owada CY, Sang CJ Jr, Khan M, Lim DS. Closure of secundum atrial septal defects with the AMPLATZER septal occluder: a prospective, multicenter, post-approval study. Circ Cardiovasc Interv. 2017;10(8).pii:e004212.

2. Gleason TG, Reardon MJ, Popma JJ, Deeb GM, Yakubov SJ, Lee JS, et al. 5-Year outcomes of self-expanding transcatheter versus surgical aortic valve replacement in high-risk patients. J Am Coll Cardiol. 2018;72(22):2687-96.

3. Reardon MJ, Van Mieghem NM, Popma JJ, Kleiman NS, Søndergaard L, Mumtaz M, et al. Surgical or transcatheter aortic-valve replacement in intermediate-risk patients. N Engl J Med. 2017;376(14):1321-31.

4. Bapat V, Rajagopal V, Meduri C, Farivar RS, Walton A, Duffy SJ, et al. Early experience with new transcatheter mitral valve replacement. J Am Coll Cardiol. 2018;71(1):12-21.

5. Taramasso M, Hahn RT, Alessandrini H, Latib A, Attinger-Toller A, Braun $D$, et al. The international multicenter TriValve Registry: which patients are undergoing transcatheter tricuspid repair? JACC Cardiovasc Interv. 2017;10(19):1982-90.

6. Stone GW, Sabik JF, Serruys PW, Simonton CA, Généreux P, Puskas J, et al. Everolimus-eluting stents or bypass surgery for left main coronary artery disease. N Engl J Med. 2016;375(23):2223-35.

7. Tajti P, Karmpaliotis D, Alaswad K, Jaffer FA, Yeh RW, Patel M, et al. The hybrid approach to chronic total occlusion percutaneous coronary intervention: update from the PROGRESS CTO Registry. JACC Cardiovasc Interv. 2018;11(14):1325-35

8. Andreassi MG, Piccaluga E, Guagliumi G, Del Greco M, Gaita F, Picano E. Occupational health risks in cardiac catheterization laboratory workers. Circ Cardiovasc Interv. 2016;9(4):e003273.

9. Andreassi MG, Piccaluga E, Gargani L, Sabatino L, Borghini A, Faita F, et al. Subclinical carotid atherosclerosis and early vascular aging from long-term low-dose ionizing radiation exposure: a genetic, telomere, and vascular ultrasound study in cardiac catheterization laboratory staff. JACC CardiovasC Interv. $2015 ; 8(4): 616-27$.

10. Barbosa AHP, Medeiros RB, Corpa AMR, Souza MT, Barbosa PL, et al. Prevalência de opacidades do cristalino $m$ cardiologistas intervencionistase profissionais atuantes na área de hemodinâmica no Brasil. Arq Bras Cardiol. 2019; 112(4):392-399.

11. Sciahbasi A, Frigoli E, Sarandrea A, Calabrò P, Rubartelli P, Cortese B, et al. Determinants of radiation dose during right transradial access: insights from the RAD-MATRIX study. Am Heart J. 2018 Feb;196:113-8.

12. Plourde G, Pancholy SB, Nolan J, Jolly S, Rao SV, Amhed I, et al. Radiation exposure in relation to the arterial access site used for diagnostic coronary angiography and percutaneous coronary intervention: a systematic review and meta-analysis. Lancet. 2015;386(10009):2192-203. 